\title{
Dual inhibitory action on aldosterone by combined angiotensin receptor antagonism and neprilysin inhibition
}

\author{
Kouichi Tamura, Ryu Kobayashi, Sona Haku, Kengo Azushima and Hiromichi Wakui \\ Hypertension Research (2016) 39, 753-755; doi:10.1038/hr.2016.71; published online 23 June 2016
}

$\mathrm{N}^{2}$ oncommunicable diseases (NCDs), such as cardiovascular disease, cancer and diabetes, are the most common causes of premature death and morbidity. Hypertension and heart failure are major NCDs that, despite advances in medical therapy, continue to be associated with high morbidity and mortality. The accumulated results of clinical studies have shown that strict blood pressure (BP) control is important for efficient suppression of target organ damage and cardiovascular complications in hypertensive patients. In Japan, the major antihypertensive drugs are calcium channel blockers, angiotensin II (Ang II) type 1 receptor (AT1R) blockers (ARBs), angiotensin-converting enzyme (ACE) inhibitors, diuretics, and $\beta$-blockers (including $\alpha$-/ $\beta$-blockers), as recommended by the international hypertension guidelines. ${ }^{1-5}$

The final common pathway in cardiovascular disease is heart failure, which is often mediated by progressive uncontrolled hypertension. Although several compensatory mechanisms occur in heart failure patients, including left ventricular remodeling and neurohormonal activation, these compensatory mechanisms gradually become maladaptive and lead to exacerbation of heart failure. Angiotensin-converting enzyme inhibitors, ARBs, $\beta$-blockers and aldosterone antagonists are designed to inhibit these maladaptive compensatory changes and have beneficial effects in heart failure patients with reduced ejection fraction. ${ }^{6}$ However, despite

K Tamura, R Kobayashi, S Haku, K Azushima and H Wakui are at Department of Medical Science and Cardiorenal Medicine, Yokohama City University Graduate School of Medicine, Yokohama, Japan E-mail: tamukou@med.yokohama-cu.ac.jp treatment with these recommended drugs, mortality from heart failure remains high. ${ }^{7}$ Therefore, there is an urgent need for the development of innovative therapeutic agents that better control BP and have therapeutic potential in the context of heart failure.

The natriuretic peptide system consists primarily of three well-characterized and structurally similar peptides, each of which is a distinct gene product: atrial natriuretic peptide (ANP) and B-type natriuretic peptide (BNP), produced mainly by cardiomyocytes, and C-type natriuretic peptide (CNP), produced mostly by endothelial and renal cells. These natriuretic peptides (ANP, BNP and $\mathrm{CNP}$ ) interact with their respective receptors, guanylyl cyclase-A (GC-A) and guanylyl cyclase-B (GC-B). ANP and BNP bind to GC-A, and $\mathrm{CNP}$ binds to $\mathrm{GC}-\mathrm{B}$ to generate the second messenger cyclic guanosine $3^{\prime}-5^{\prime}$ monophosphate (cGMP). The cGMP produced by these interactions mediates potent natriuretic and vasodilatory properties, inhibiting the activity of the renin-angiotensin system (RAS), lowering sympathetic drive, and producing antiproliferative and antihypertrophic effects. This nucleotide therefore exerts cardioprotective and renal-protective effects. ${ }^{8}$ These natriuretic peptides (ANP, BNP and CNP) are cleared by a clearance receptor, natriuretic peptide receptor-C (NPR-C), which is not linked to a GC.

In addition, these natriuretic peptides (ANP, BNP and CNP) are cleared from the circulation via enzymatic degradation by neutral endopeptidase-24.11 (neprilysin). Neprilysin is a zinc-dependent, membranebound endopeptidase that hydrolyzes peptides on the amino side of hydrophobic residues, and is critical for the processing and catabolism of vasoactive peptides, and peptides involved in diuresis and natriuresis, for example, the natriuretic peptides, angiotensin I, bradykinin (BK) and endothelin-1 (ET-1). ${ }^{8}$ In mammals, neprilysin is widely expressed, for example, in kidney, lung and endothelial cells; vascular smooth muscle cells; cardiac myocytes, fibroblasts, neutrophils and adipocytes; the testes; and the brain. The highest concentrations are found in the renal proximal tubule.

Studies have shown dysregulation of the natriuretic peptide system in cardiovascular and renal diseases, including hypertension and heart failure. Therefore, pharmacological strategies for enhancing the actions of these natriuretic peptides (ANP, BNP and CNP) have included exogenous administration of endogenous peptides or degradation-resistant peptides as well as the use of neprilysin inhibitors. However, neprilysin also contributes to the breakdown of other vasoactive peptides with opposing physiological actions. Therefore, although neprilysin inhibitors would cause increases in the circulating levels of the natriuretic peptides and BK, they would also increase the vasoconstrictors Ang II and ET-1. Indeed, the results of clinical studies of neprilysin inhibition in the treatment of heart failure and hypertension have failed to show clear therapeutic benefits, thereby supporting the notion that clinically therapeutic benefits of neprilysin inhibition may not be realized unless there is simultaneous suppression of the RAS and/or ET-1.

LCZ696 is the first of a new class of drugs to employ this potential therapeutic strategy in cardiovascular and renal diseases. It 
combines the ARB, valsartan, and the neprilysin inhibitor prodrug sacubitril (AHU377) in a 1:1 ratio in a sodium supramolecular complex. ${ }^{9,10}$ Sacubitril is then rapidly metabolized by nonspecific esterases to the active neprilysin inhibitor LBQ657, which inhibits neprilysin, the enzyme responsible for the degradation of the natriuretic peptides and other vasoactive peptides, as described above. Therefore, the combined ARB/neprilysin inhibitor, LCZ696, is able to address two pathophysiological mechanisms underlying certain cardiovascular and renal diseases, including hypertension and heart failure: activation of the RAS and decreased sensitivity to natriuretic peptides caused by the dysregulation of the natriuretic peptide system that occurs in these pathological situations.

Clinical studies of LCZ696 in the treatment of hypertension and heart failure have shown promising therapeutic benefits. Previous studies have demonstrated that patients with mild-to-moderate hypertension treated with LCZ696 had significantly lower office and ambulatory BP than those treated with valsartan or placebo. ${ }^{11-13}$ Furthermore, in the Prospective Comparison of ARNI With ACEI to Determine Impact on Global Mortality and Morbidity in Heart Failure (PARADIGM-HF) trial, LCZ696 significantly reduced mortality and hospitalization for heart failure in addition to lowering BP. Its performance was superior to that of enalapril in heart failure patients with reduced ejection fraction, ${ }^{14}$ and the US Food and Drug Administration approved LCZ696 for the treatment of heart failure.

Activation of the circulating and tissue RAS also stimulates the aldosterone-mineralocorticoid receptor pathway and promotes the cardiovascular remodeling that accompanies hypertension and chronic kidney disease. ${ }^{15,16}$ It is well-known that ARBs decrease aldosterone production and increase natriuresis by blocking adrenal AT1R. ARBs also decrease cardiac, vascular and renal injuries by decreasing AT1R-, mineralocorticoid receptor- and aldosteronemediated hypertrophy; inflammation; and fibrosis. However, long-term administration of ARBs, like long-term administration of ACE inhibitors, causes circulating aldosterone concentrations to 'escape' back to baseline levels, providing the rationale for the concurrent use of antagonists of the aldosterone-mineralocorticoid receptor pathway. Although it is thought that neprilysin enhances the natriuretic peptide-evoked signals that can block Ang II/AT1R-induced aldosterone production, the exact relevant mechanisms of the beneficial inhibitory effects of LCZ696 on the aldosteronemineralocorticoid receptor pathway remain to be elucidated. Indeed, in one study, LCZ696 treatment significantly increased the circulating ANP and cGMP concentrations, but did not affect plasma aldosterone concentration compared with placebo in hypertensive patients. ${ }^{11}$

Interestingly, Miura et al., ${ }^{17}$ as reported in this issue, examined the effects of valsartan, ARB and LBQ657-the active moiety of LCZ696 - on aldosterone synthesis in a human adrenocortical cell line (NCI-H295R cells) to investigate the possible mechanisms of the beneficial effects of LCZ696. ${ }^{17}$ Although there was no difference in the dissociation from AT1R between valsartan +LBQ657 and valsartan alone, the binding affinity of valsartan+LBQ657 to AT1R was greater than that of valsartan alone in an AT1R-expressing human embryonic kidney cell-based living assay. ${ }^{17}$ The authors

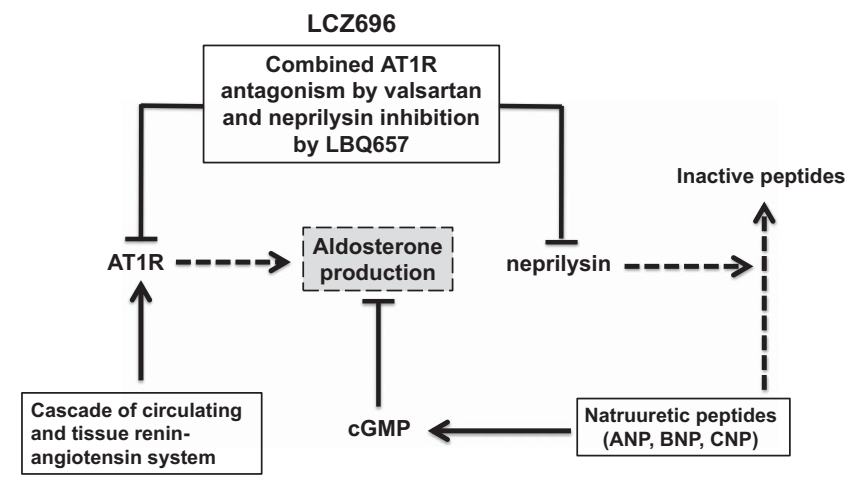

Figure 1 Schema of the dual inhibitory action on aldosterone production by combined angiotensin receptor antagonism and neprilysin inhibition. The dotted arrows indicate inhibited action or cascade by LCZ696. ANP, atrial natriuretic peptide; AT1R, angiotensin II type 1 receptor; BNP, B-type natriuretic peptide; cGMP, cyclic guanosine 3'-5' monophosphate; CNP, C-type natriuretic peptide; LBQ657, active moiety of LCZ696; LCZ696, valsartan/sacubitril.

also showed that the natriuretic peptide-mediated suppression of aldosterone synthesis was further augmented by co-administration of LBQ657. ${ }^{17}$ Collectively, the authors demonstrated that the combined AT1R antagonism by valsartan and LBQ657 neprilysin inhibition significantly enhanced the natriuretic peptide-mediated signaling effects to suppress Ang II-AT1R-induced aldosterone production in adrenocortical cells, without affecting the expression of aldosterone synthase genes ${ }^{17}$ (Figure 1). The results revealed a dual inhibitory action of LCZ696 on the aldosterone cascade as an important drug property and revealed a new aspect of the mechanism of LCZ696-mediated beneficial effects in cardiovascular and renal physiology, thereby contributing an interesting finding to the field of hypertension research.

\section{CONFLICT OF INTEREST}

The authors declare no conflict of interest.

\section{ACKNOWLEDGEMENTS}

KT received research grants from Daiichi Sankyo, Kyowa-hakko Kirin, Mochida, Chugai,

Takeda, Novartis, MSD, Pfizer, AstraZeneca, Ono Pharmaceutical and Dainippon-Sumitomo, and honoraria from Mochida, Dainippon-Sumitomo, Nippon Boehringer Ingelheim, Kyowa-hakko Kirin, Daiichi Sankyo, Astellas, Chugai, Otsuka Pharmaceutical, Pfizer, Shionogi, Takeda and Sanofi.

1 Mancia G, Fagard R, Narkiewicz K, Redon J, Zanchetti A, Bohm M, Christiaens T, Cifkova R, De Backer G, Dominiczak A, Galderisi M, Grobbee DE, Jaarsma T, Kirchhof P, Kjeldsen SE, Laurent S, Manolis AJ, Nilsson PM, Ruilope LM, Schmieder RE, Sirnes PA, Sleight P, Viigimaa M, Waeber B, Zannad F. 2013 ESH/ESC Guidelines for the management of arterial hypertension: the Task Force for the management of arterial hypertension of the European Society of Hypertension (ESH) and of the European Society of Cardiology (ESC). J Hypertens 2013; 31: 1281-1357.

2 Go AS, Bauman MA, Coleman King SM, Fonarow GC, Lawrence W, Williams KA, Sanchez E. An effective approach to high blood pressure control: a science advisory from the American Heart Association, the American College of Cardiology, and the Centers for Disease Control and Prevention. Hypertension 2014; 63: 878-885.

3 James PA, Oparil S, Carter BL, Cushman WC, Dennison-Himmelfarb C, Handler J, Lackland DT, LeFevre ML, MacKenzie TD, Ogedegbe O, Smith SC Jr, Svetkey LP, Taler SJ, Townsend RR, Wright JT Jr, Narva AS, Ortiz E. 2014 evidence-based guideline for the management of high blood pressure in adults: report from the panel members appointed to the Eighth Joint National Committee (JNC 8). JAMA 2014; 311: 507-520.

4 Weber MA, Schiffrin EL, White WB, Mann S, Lindholm LH, Kenerson JG, Flack JM, Carter BL, Materson BJ, Ram CV, Cohen DL, Cadet JC, Jean-Charles RR, Taler S, Kountz D, Townsend RR, Chalmers J, Ramirez AJ, Bakris GL, Wang J, 
Schutte AE, Bisognano JD, Touyz RM, Sica D, Harrap SB. Clinical practice guidelines for the management of hypertension in the community: a statement by the American Society of Hypertension and the International Society of Hypertension. J Clin Hypertens (Greenwich) 2014; 16: 14-26.

5 Shimamoto K, Ando K, Fujita T, Hasebe N, Higaki J, Horiuchi $\mathrm{M}$, Imai $\mathrm{Y}$, Imaizumi $\mathrm{T}$, Ishimitsu $\mathrm{T}$, Ito $\mathrm{M}$, Ito $\mathrm{S}$, Itoh $\mathrm{H}$, Iwao $\mathrm{H}$, Kai $\mathrm{H}$, Kario $\mathrm{K}$, Kashihara $\mathrm{N}$, Kawano Y, Kim-Mitsuyama S, Kimura G, Kohara K, Komuro I, Kumagai $H$, Matsuura $H$, Miura K, Morishita R, Naruse M, Node K, Ohya Y, Rakugi H, Saito I, Saitoh S, Shimada K, Shimosawa T, Suzuki H, Tamura K, Tanahashi N, Tsuchihashi T, Uchiyama M, Ueda S, Umemura S. The Japanese Society of Hypertension Guidelines for the management of hypertension (JSH 2014). Hypertens Res 2014; 37: 253-390.

6 Yancy CW, Jessup M, Bozkurt B, Butler J, Casey DE Jr, Drazner MH, Fonarow GC, Geraci SA, Horwich T, Januzzi JL, Johnson MR, Kasper EK, Levy WC, Masoudi FA, McBride PE, McMurray JJ, Mitchell JE, Peterson PN, Riegel B, Sam F, Stevenson LW, Tang WH, Tsai EJ, Wilkoff BL. 2013 ACCF/AHA guideline for the management of heart failure: a report of the American College of Cardiology Foundation/ American Heart Association Task Force on practice guidelines. Circulation 2013; 128: e240-e327.

7 Mozaffarian D, Benjamin EJ, Go AS, Arnett DK, Blaha MJ, Cushman M, de Ferranti S, Despres JP, Fullerton HJ, Howard VJ, Huffman MD, Judd SE,
Kissela BM, Lackland DT, Lichtman JH, Lisabeth LD, Liu S, Mackey RH, Matchar DB, McGuire DK, Mohler ER 3rd, Moy CS, Muntner P, Mussolino ME, Nasir K, Neumar RW, Nichol G, Palaniappan L, Pandey DK, Reeves MJ, Rodriguez CJ, Sorlie PD, Stein J, Towfighi A, Turan TN, Virani SS, Willey JZ, Woo D, Yeh RW, Turner MB. Heart disease and stroke statistics-2015 update: a report from the American Heart Association. Circulation 2015; 131: e29-322.

8 Mangiafico S, Costello-Boerrigter LC, Andersen IA, Cataliotti A, Burnett JC Jr. Neutral endopeptidase inhibition and the natriuretic peptide system: an evolving strategy in cardiovascular therapeutics. Eur Heart J 2013; 34: 886-893c.

9 Monge M, Lorthioir A, Bobrie G, Azizi M. New drug therapies interfering with the renin-angiotensinaldosterone system for resistant hypertension. J Renin Angiotensin Aldosterone Syst 2013; 14: 285-289.

10 Hubers SA, Brown NJ. Combined angiotensin receptor antagonism and neprilysin inhibition. Circulation 2016; 133: 1115-1124.

11 Ruilope LM, Dukat A, Bohm M, Lacourciere Y, Gong J, Lefkowitz MP. Blood-pressure reduction with LCZ696, a novel dual-acting inhibitor of the angiotensin II receptor and neprilysin: a randomised, double-blind, placebo-controlled, active comparator study. Lancet 2010; 375: 1255-1266.

12 Kario K, Sun N, Chiang FT, Supasyndh O, Baek SH, Inubushi-Molessa A, Zhang Y, Gotou H, Lefkowitz M, Zhang J. Efficacy and safety of LCZ696, a first-in-class angiotensin receptor neprilysin inhibitor, in Asian patients with hypertension: a randomized, double-blind, placebo-controlled study. Hypertension 2014; 63 698-705.

13 Ito S, Satoh M, Tamaki Y, Gotou H, Charney A, Okino N, Akahori M, Zhang J. Safety and efficacy of LCZ696, a first-in-class angiotensin receptor neprilysin inhibitor, in Japanese patients with hypertension and renal dysfunction. Hypertens Res 2015; 38 269-275.

14 McMurray JJ, Packer M, Desai AS, Gong J, Lefkowitz MP, Rizkala AR, Rouleau JL, Shi VC, Solomon SD, Swedberg K, Zile MR. Angiotensin-neprilysin inhibition versus enalapril in heart failure. N Engl J Med 2014; 371: 993-1004.

15 Mule G, Nardi E, Guarino L, Cacciatore V, Geraci G, Calcaterra I, Oddo B, Vaccaro F, Cottone S. Plasma aldosterone and its relationship with left ventricular mass in hypertensive patients with early-stage chronic kidney disease. Hypertens Res 2015; 38: 276-283.

16 Cuspidi C, Tadic M, Sala C. Aldosterone and abnormal left ventricular geometry in chronic kidney disease. Hypertens Res 2015; 38: 314-316.

17 Miura S, Suematsu Y, Matsuo Y, Tomita S, Nakayama A, Goto M, Arimura T, Kuwano T, Yahiro E, Saku K. The angiotensin II type 1 receptor-neprilysin inhibitor LCZ696 blocked aldosterone synthesis in a human adrenocortical cell line. Hypertens Res 2016; 39: 758-763. 